\title{
A Comparative Study of The Effect of Bologna Process on the Italian Higher Education and Czech Higher Education ${ }^{1}$
}

\author{
Jie Liu
}

\begin{abstract}
It's been over 60 years since the very beginning of European integration when European Coal and Steel Community was established in 1951. In terms of developmental stage, European integration has already passed economic integration and political integration. Profound educational integration is the next development goal of European community. As the spillover effect of European economic and political integration, Bologna Process proposed a promising solution to establishing a European Higher Education Area in the hopes of strengthening integration of higher education across Europe. As stated in the Prague Communiqué, ministers reaffirmed that efforts to promote mobility must be continued to enable students, teachers, researchers and administrative staff to benefit from the richness of the European Higher Education Area including its democratic values, diversity of cultures and languages and the diversity of the higher education system (Prague Communiqué, 2002, p. 1). In the last two decades, it has witnessed that academic exchanges across Europe has increased a lot. Italy, as one of the most developed Western European members, is among the first which implemented two-cycle system. Czech Republic, as an emerging member in the Eastern Europe, has also been very supportive of Bologna Process. One of the major targets of Bologna Process is to facilitate students' mobility. This project studies how much effect has Bologna Process exerted on students mobility in the two countries' higher education, and find out the limitation to students mobility that Bologna Process has not solved yet, and then compare the situations of students mobility between the two countries, one representing the west of Europe, the other the east.
\end{abstract}

Keywords: Bologna Process, Czech Republic, Italy, higher education, students' mobility

\section{Students’ Mobility of Italian Higher Education after Bologna Process}

Before the start of the Bologna Process, Italy was one of those countries involved in the Process which did not have a two-cycle type degree structure (Gasperoni, 2011). During the reform, Italy was actively implementing the two-cycle system in the hopes of creating a

\footnotetext{
${ }^{1}$ This study was presented at the Education, Society, and Reform Research (EDUSREF 2018) between 6-7 April 2018 in Ankara, Turkey.

${ }^{2}$ Charles University, Prague, Czech Republic; University of Bari Aldo Moro, Bari, Italy. 42786904 [at] fsv.cuni.cz
} 
system of education more comparable to the rest of Europe. This structural reform and the accompanying measures are called for in the Bologna Declaration as serving the strategic objective aim of contributing to student mobility. Actually, two aims are declared:

- To increase the attractiveness of higher education in Europe for students from other parts of the world, and

- To facilitate intra-European mobility.

Without explicitly stating so, the Bologna Process aims primarily to increase the following modes of student mobility: (a) inbound mobility for whole degree programs from other parts of the world, and (b) temporary (between three months and a year) inbound and outbound mobility between European countries (Teichler, 2009b; Wächter, 2008).

Undoubtedly, Italy has always been a popular destination of study to foreign students for its culture, history, architecture, art, fashion, food, people and weather. Those third-country students who want to study in Italy but somehow fail to get admission into an Italian university can enjoy a study stay in Italy as an Erasmus student from another European country if they are full-time students there. Exchange students who are originally from outside Europe are able to study in Italy through Erasmus Program and are generally handled as European exchange students. In this sense, Bologna Process has indeed increased the attractiveness of higher education in Europe for students from extra-Europe. To increase international competitiveness of higher education, most Italian universities have official websites in both Italian and English, some even have German, Spanish and Chinese websites. Italian education system sets the same requirement for both EU and non-EU foreign students, which indicates that the country is equally open to all foreign students. According to the report published by MIUR in 2011, foreign students (both EU and non-EU) have been steadily increasing in absolute terms and as a percentage of the overall student population over the last decade. In the academic year 2000/2001 right after the Bologna Declaration, 5,509 foreign students - at both undergraduate and graduate levels - enrolled in Italian universities representing $1.9 \%$ of the students that enrolled to university. In that same year, there were overall 25,769 foreign students in the higher education system, accounting for $1.5 \%$ of the total student body. In 2009/2010, 12,188 foreign students enrolled to university (i.e. $4.2 \%$ of students enrolled) and the total population of foreign students amounted to 59,509 individuals (i.e. 3.3\% of the total students population) (MIUR, 2011: 68; Durazzi, 2014).

Furthermore, some steps have been taken in order to make the system more open, both inward and outward. As far as inward mobility is concerned, two main items stand out: (i) the entry tests to Medicine have been run for the first time in 2012 in English language and simultaneously in Italy and abroad (in the Italian consulates). This is an example of an effort made to open up the system to foreign applicants, going beyond linguistic barriers and physical barriers, the latter being especially relevant for applicants from non-EU countries that would face visa issues to go to a foreign country to take the test; (ii) the Marco Polo programme11, developed within CRUI, and currently managed independently by individual universities, aimed to increase the inflow of Chinese students, as a part of a broader attempt to 
strengthen economic relations with China at the national level. The program prompted universities to put in place policies to actively attract Chinese students, for instance by stepping up the offer of Italian language courses to Chinese students and streamlining the administrative procedures for visa and enrolment matters. In terms of outward mobility, high schools have been required from the early 2000s to release high school diplomas in English, French, German and Spanish as well to ease the application process of Italian students to foreign universities. Thus, the Italian system is in principle extremely open to foreign applicants (Durazzi, 2014).

As for Italian intra-European mobility, Erasmus program has been the major scheme for outbound Italian students and inbound foreign students from other European countries. Institutionally, the three-cycle system and ECTS system as well as more English-taught courses has made students mobility more feasible. And the country has always been one of the most popular host countries for inbound Erasmus students and a major country which sends one of the largest number of outbound Erasmus students. As can be seen in the Linear Graph 1 in the later comparison part of this article, the growth of the number of Italian outbound Erasmus students has been steady until 2014 when there was a slight decrease and 2015 when there was a dramatic increase. The growth of inbound Erasmus students has been steady too in the last couple of years (Linear Graph 2).

\section{Limitations to Students' Mobility in Italian Higher Education}

Behind the positive effect that Bologna Process has brought to Italian higher education, there are also limitations and problems to students' mobility.

After the introduction of new three-year degree program, Italian universities were facing the problem of how to convert the classic courses of old long-period degree program into that of the new short degree program. Since one of Bologna Process's goals is to make graduates who have completed a bachelor program be ready for labor market directly, some faculties instituted quasi-professional courses of studies; others instituted basic courses of studies (Radičev, Di Stefano, 2010), consequently the same specialty in different universities had become heterogeneous from each other. As a result, a reduction of students' national mobility happened, because it was more difficult for students to move from one faculty to the same faculty of another university (Radičev, Di Stefano, 2010). Another kind of consideration can be done from the point of view of the compatibility of 1st cycle (undergraduate) and 2nd cycle (graduate). Depending on whether 1st cycle degree was "general" or "specific", 2nd cycle degree might have been conceived in different ways. Most faculties conceived 2nd cycle degree as a complement of bachelor and privileged closer examination of the subjects of the 1st cycle. Other faculties conceived 2nd cycle degree as an addition to the bachelor and privileged the study of new subjects (Radičev, Di Stefano, 2010). In terms of articulation between bachelor's program and master's program, such disparity has affected Italian students' national mobility.

As for international mobility, Italian students are also facing some restrictions. Bologna Process has made structure of degree programs more homogeneous in terms of study periods, but it hasn't made curriculum of different countries more comparable. According to an 
interviewed Italian student who studies Psychiatric Rehabilitation Techniques, she cannot do an Erasmus study abroad or a master degree abroad for there is not a compatible match between her major at home university and the one abroad. If she went abroad for a master degree which is close to her major, it would be very difficult for her to find a job after she came back to Italy since the overseas master degree cannot be properly recognized in Italy. Another Italian student also refused to apply for Erasmus program, because he was afraid his study at home university in Italy would be negatively affected. He said he might have to extend her study period after coming back from an Erasmus stay abroad. Besides curriculum compatibility, language is also another concern for students who want to apply for Erasmus program. Many foreign universities don't offer courses in a language that Italian applicants can speak, so their choices are narrowed down sharply. Incoming mobility students studying in Italy also encounter some limitations and problems. Some programs can only be taught in Italian, which forms a language barrier for those foreign students who don't speak Italian. These students have no choice but to struggle with self-study.

Apart from academic factors, socio-economic status also limits Italian students' mobility. A large-scale study of 21,145 Erasmus and non-Erasmus students in seven nations found that financial constraint was cited as the most important reason for non-participation (Vossensteyn, 2010). Souto-Otero (2008) found that, on average, those who participated in Erasmus in 20042005 came from more privileged backgrounds - with a higher percentage of parents in professional or executive occupations, more with at least one parent who had attended higher education and with reported parental income that was higher than in the general population. This finding confirms previous studies which found that students who study abroad are a more select group than students who do not (Teichler \& Jahr, 2001; Teichler, 2004) (Ballatore, Ferede. 2013). A local interviewed Italian student complained about the insufficient fund provided for Erasmus program. She said the fund barely covers the rent in some Western European countries like France, Belgium and UK. While those students who have higher socio-economic status can easily take part in international mobility abroad. In this sense, Bologna Process has further exposed the inequality of higher education in Italy as well as the whole Europe.

Another limitation has also been found that the same five Western European countries have been Italian students' favorite destinations for Erasmus mobility. Spain, France, Germany, UK and Portugal have been the top five on the list in the last couple of years (Table 2). According to an interview with three Italian students, they all agreed that the west was more advanced than the east. One of them said the education quality in the west must be better than the Eastern Europe. If we take a look at the incoming Erasmus students studying Italy (Table 3), we will see Spain, France, Germany, Poland and Turkey have been the top 5 countries where students come from for mobility in Italy. Bologna Process aims to strengthen the mobility across the whole Europe, not just across a particular part of Europe. In this sense, Bologna Process has not yet increased much students' mobility from the Italy to the east. 


\section{Questionnaire Survey Result of Mobility in Italian Higher Education}

This project carried out a questionnaire survey on 30 students with a view to have a understanding of how a sample of students see the impact of Bologna Process on their mobility. There were three groups of students. 10 Italian students who have been abroad for a mobility or will go abroad for a one, 10 inbound Erasmus students in Italy and 10 Italian students who did not and will not go abroad for mobility. Most of the Italian students want to do Erasmus for experiencing different culture. And most of them choose the more advanced Western Europe as destination. They all think three-cycle system and ECTS transfer system have some positive effect on their mobility. And no one agrees that mobility abroad negatively affect their study at home university. Regarding the inbound Erasmus students in Italy, most of them are also holding a positive attitude towards three-cycle system and ECTS transfer system. Those who did not or do not plan to go abroad for Erasmus complained about the insufficient fund and also worry about the negative effect of mobility abroad on their study at home university.

\section{Students’'Mobility of Czech Higher Education after Bologna Process}

Czech Republic, though has a geographic advantage locating in the center of Europe, was not a popular destination at all for international students. Since the Bologna Process, it has been witnessed that more and more foreign students including degree students and short-term students choose to study in this small but beautiful country. Czech higher education introduced three cycle system and the European Qualifications Framework (EQF) after Bologna Declaration and the Prague Communique. In order to better integrate into European Higher Education Area (EHEA), Czech Republic has been trying to offer lessons in as much English as possible. At the beginning of 21 st century, it was noticed that at some universities there was a lack of programs taught in foreign languages when they were trying to do their best for inbound Erasmus students. In addition to the requirements of recognition of qualification, Czech higher education institutions realized that they had to improve their ability to deliver lessons in foreign languages (Stastna, 2001). According to Eurydice of European Commission, the Czech Ministry of Education, Youth and Sports has included mobility of academic staff of public higher education institutions as a priority in its Strategic Plan, which envisages programs to support staff mobility as well as the establishment of suitable conditions for the permanent employment of foreign experts. The Strategic Plan also contains recommendations to higher education institutions: they are advised to support twoway international mobility of researchers; for academic staff, long-term mobility should form part of career progression; for other (administrative) staff, mobility should become a normal expectation, too. The Strategy for Lifelong Learning in the Czech Republic refers to academic staff mobility as a means to develop quality in teaching and research. In the context of the National Policy of Research, Development and Innovation of the Czech Republic, enabling academic staff to do research at major European and world workplaces is seen as a contribution to the provision of quality human resources for R\&D (European Commission, 2013). The teachers who experienced mobility abroad contribute not only to innovation of curricula of Czech higher education institutions but also the Foreign language ability of Czech higher education. In this sense, academic staff's mobility is in the service of student's mobility. As language is no longer a barrier and living cost is lower than its western 
counterparts, more and more foreign students choose to come to Czech Republic for study, either for Erasmus exchange or degree study.

In 2001, there were only 9000 foreign students studying in Czech Republic. In 2010 the number reached around 38,000 (czech.cz, 2011). In 2014, EU statistics listed the Czech Republic as the 12th most popular destination for Erasmus students in Europe. In 2015 Czech Republic was the home to 42,048 international students. In 2016, international students constituted about 14\% of all undergraduates (timeshighereducation.com, 2017). In 2018, it is 43,517 (masterdegree.net, 2018), in which the number of non-European students has increased a lot. The institutional reform of Czech higher education after Bologna Process, namely the introduction of three-cycle system and ECTS, has provided foreign students, especially non-European students, a great chance to go to another EU country for mobility study, which is a very attractive offer. It is like you can get at least two study experiences in two different countries where you could have a diversified academic experience and adopt another foreign language if you are enrolled in one EU university. Moreover, since the ECTS is like the "academic currency" which can circulate around Europe without hindrance, and the degree is also mutually recognized across the continent, foreign students have more flexibility to look for jobs without being limited in a single state, which means they have more chances and choices after graduation. For non-European students, It is really hard to neglect such an attractive and huge shared resource when deciding where to go for study abroad. Given the geographical advantage and relatively lower price as well as the solved language problem, Czech Republic is getting more and more popular among foreign students. One of the original intentions of Bologna Process is to make European education more united and globally more competitive vis-à-vis the USA. In the case of what happened in Czech Republic in the last two decades and in terms of how it has become more attractive to foreign students, it is working.

As for Czech students' outbound mobility, the situation is a little more complicated. Unlike the situation back in 2001 when recognition of credits points after exchange study was still a problem, such as credits awarded were not always considered to be compatible if the exchange is organized between a 'research' and a 'teaching' university, some institutions compared the details between the courses attended overseas and the ones at home university rather than just assessed the completed study as a whole, some students were afraid to participate in a stay abroad because of language barriers, low fund, delayed payment of fund etc. (Stastna, 2001) Nowadays, many problems have been solved or at least the situation has been significantly improved. With the introduction of three-cycle system, quality assurance, diploma supplement and ECTS under the Bologna Process, mutual recognition has been more convenient than before, more and more Czech students choose to go abroad for an exchange study. In 2005, around 4200 Czech undergraduates went abroad for Erasmus stay (czechuniversities.com, 2006). According to ICEF Monitor, Samuel Vetrak, CEO of Student Marketing, that almost 12,000 Czech tertiary education students (approximately 3\% of the tertiary student population) studied abroad for one year or more. If we take a closer look at how Czech students make their decisions, we can see reasons to go abroad for an exchange experience can be very individualized as well as very common. According to some interviews this project has carried out, a French translation major student applied for two 
Erasmus study stays in Paris because she likes French culture very much even it meant she had to extend her master program study period after coming back to Czech Republic. Two other students who chose to go to Slovakia and Hungary respectively because the living cost in the two countries are relatively lower and they both just wanted a overseas experience on their resumes. According to Linear Graph 1, the growth of outbound Czech students has been steady mostly. Since the country started Erasmus program in 1998, we cannot directly see how much impact Bologna Process has exerted on Czech student's international mobility. Still it is obvious that three-cycle system, quality assurance, diploma supplement and ECTS of Bologna Process have made Czech students' outbound mobility more convenient and more efficient, and have at least provided Czech students with a choice.

According to the survey carried out in 2014 by European Association for International Education (EAIE). Following on from the Bologna Process, Higher education institutions strive to develop international collaboration within their activities, in both the joint science projects and also, to a great extent, in the support of mobility of international students and academic staff. The number of foreign students from European and non-European countries studying in the Czech Republic continues to grow (EAIE. 2014 ). If we single out the inbound Erasmus students studying in Czech Republic, we can see a steady growth in number too (see Linear Graph 2). All in all, Bologna Process has made Czech higher education increasingly international, competitive and attractive to the rest of the world.

\section{Limitations to Students' Mobility in Czech Higher Education}

Despite the increased number of incoming international students, we have to notice that almost half of these international students are from the neighbor Slovakia, although the total number of them is declining. In 2015, 22,224 Slovaks were studying in the Czech Republic, in 2016, 22,178 and in 2017 the number declined to 21,481 (prague.tv, 2018). Numbers from Russia $(5,900)$, Ukraine $(2,900)$ and Kazakhstan $(1,600)$ have been growing, and now collectively account for nearly a quarter of international students and a majority of those from outside the European Union (timeshighereducation.com, 2017). It means that although number of non-European international students is increasing, still the source countries of incoming students are not diversified enough. The same situation also happens in the outbound mobility. Regarding the destination countries for Czech students to go to for study, Slovakia again is the leading destination. In 2011, Slovakia hosted 4,979 students from the Czech Republic. Germany, the UK, the US, Austria, and France were among other popular destinations. Mr. Samuel Vetrak pointed out that "these six destinations attracted $80 \%$ of all Czech students (monitor.icef.com, 2014).

Another problem is disparity between Czech cities as destinations of foreign students. In 2006, 6000 out of 24000 foreign students signed up for courses in the capital, at Prague's Charles University (Johnston, 2007). In the 2012 - 2013 academic year more than 1,300 foreign students studied at 17 university faculties as part of the exchange programme, putting Charles University in 7th place amongst the thousands of universities taking part in the Erasmus programme, according to figures published by the European Commission (Press and PR Office of Charles University in Prague, 2014). Masaryk University in Brno had been the most 
satisfied university from 2013 to 2015 based on the evaluations of thousands of international students participating in a short-term study visit. According to Erasmus + statistics 2014 issued by European Commission, three universities in Prague and Masaryk University took 4 places in the top five receiving institutions. Two universities in Prague and Masaryk University in Brno were among the top five sending institutions. We can see most inbound international students come to and most outbound Czech students go out from Prague and Brno, which means the gap between the two major cities and other Czech cities has been widened in terms of mobility of higher education.

Another factor also affect the student's decision on mobility. According to two interviews with a Czech student and a Korean student who are studying at Charles University, the Czech student who went to Budapest for an Erasmus stay had to extend his study period after he returned to Prague because the normal time left after he came back was not enough for him to finish a thesis and state exams. And the Korean student said she wanted to graduate on time and did not want to extend her study period, so she did not apply for Erasmus stay at all. So even the recognition of ECTS after Bologna Process has become much easier, students of Czech higher education normally cannot graduate within a standard study period if they want to have an Erasmus stay abroad, which would disturb students' study plan. And some students don't like that, so they just give up application for exchange study abroad at all.

We can single out the data of top 5 countries which receive Czech Erasmus students and send Erasmus students to Czech Republic, and see if mobility destinations and senders are diverse or more concentrated in a particular part of Europe. Regarding destinations for Czech students to go to for Erasmus from 2009 to 2016, Germany, France, Spain and UK have been the major four popular countries (Table 2). While Spain, France and Turkey have been on the top 5 on the list, which send students to study in Czech Republic. It is glad to see more and more students from Slovakia and Turkey are coming to Czech Republic for Erasmus, but in the last couple of years most incoming students have been from the three major Western European countries which are Spain, France and Germany (Table 3).

\section{Questionnaire Survey Result of Mobility in Czech Higher Education}

Same as the questionnaire survey on students' mobility of Italian higher education, this project also found 10 Czech students who have been abroad for a mobility or plan for an mobility in the near future, 10 inbound Erasmus students in Czech Republic, and 10 Czech students who haven't been abroad for mobility or do not plan for a mobility abroad. Let's start with the outbound Czech students. Most students choose Western Europe for mobility and quite agree that three-cycle system and ECTS transfer system have made their international mobility more feasible and convenient. 6 students believe mobility abroad negatively affect their study at home university. As for inbound Erasmus students, 8 of them came to Czech Republic because of the affordable living cost. They also confirmed the positive effect of three-cycle system and ECTS transfer system on their mobility. Among the Czech students who did not or do not plan to do an Erasmus, most of them think the fund is not enough and mobility abroad will negatively affect their study at home university. 


\section{Comparison between Italy and Czech Republic in Mobility of Higher Education}

Erasmus program started in 1987, in the first year Italy sent 220 Erasmus students abroad, while Czech Republic had not initiated Erasmus program until 1998 when they sent 879 students abroad. Both countries' outbound and inbound mobility have been growing steadily as shown in Linear Graph 1 and 2. And to third-country students, both Italy and Czech Republic are more attractive for higher education in the recent years.

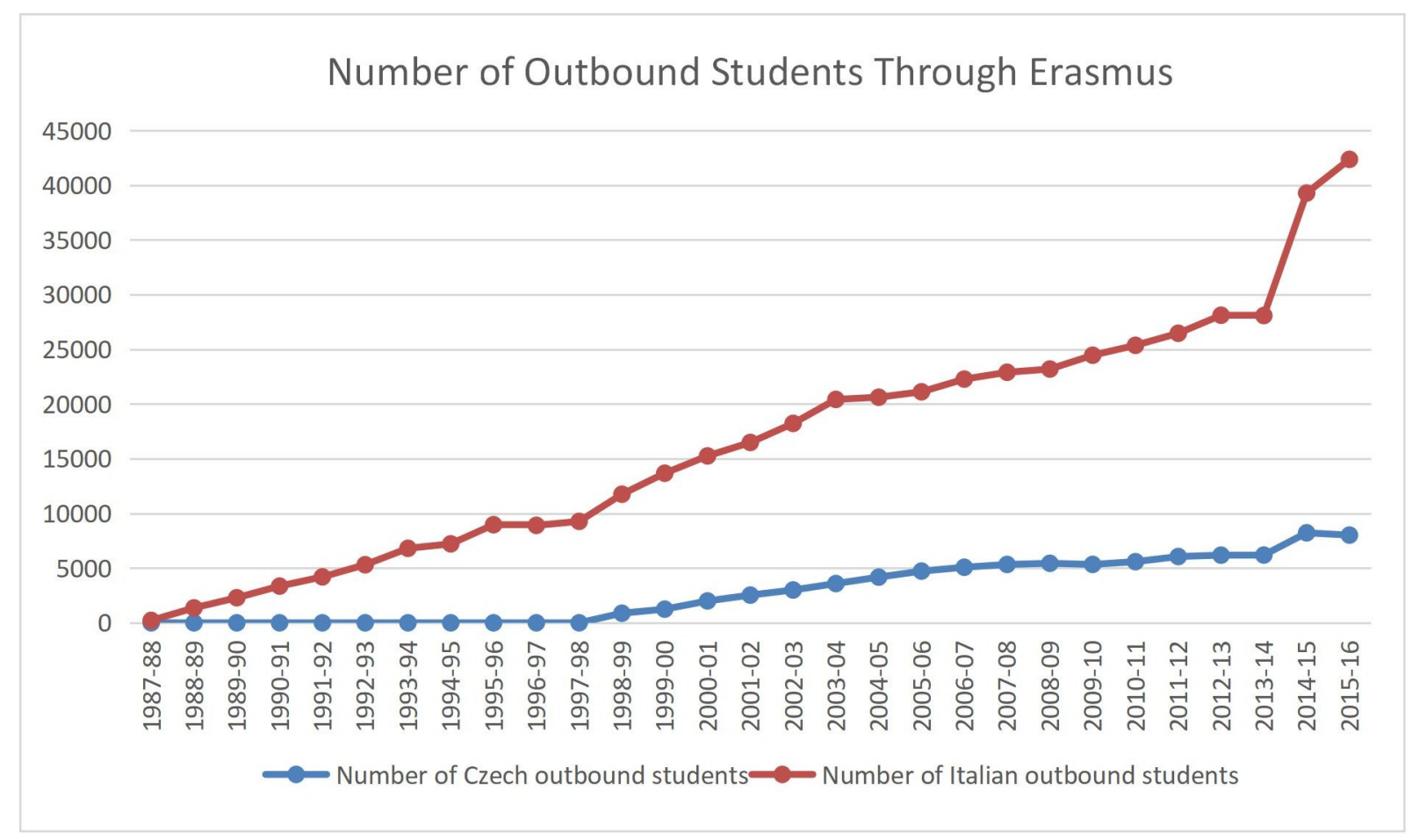

Linear Graph 1. Number of Outbound Students Through Erasmus

(Data is drawn from statistics report by European Commission)

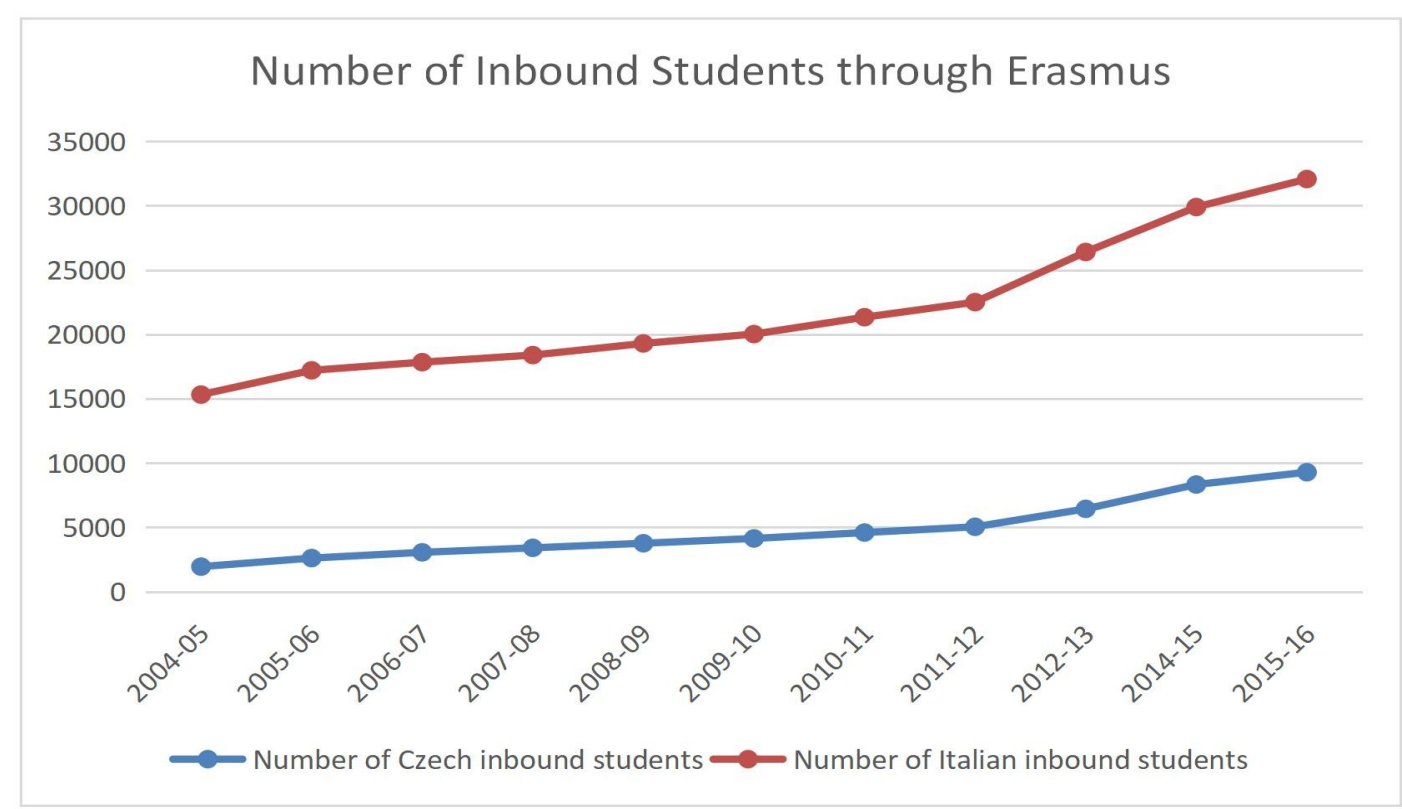

Linear Graph 2. Number of Inbound Students Through Erasmus

(Data is drawn from statistics report by European Commission. Data of inbound Erasmus student from 1987 to 2003 cannot be found) 
Moreover, another statistics of year 2007-2011 can tell that both Italian and Czech students who went abroad for mobility had a higher graduation rate than those who did not since the share of outgoing Erasmus students as a percentage of the graduation population is larger than that of the total student population (Table 1).

Table 1

Share of outgoing Erasmus students*

\begin{tabular}{|c|c|c|c|c|}
\hline \multicolumn{5}{|c|}{$\begin{array}{l}\text { Share of outgoing Erasmus students of the total student population in the two } \\
\text { countries respectively }\end{array}$} \\
\hline Year & $2007 / 08$ & $2008 / 09$ & $2009 / 10$ & $2010 / 11$ \\
\hline Italy & $0.91 \%$ & $0.96 \%$ & $1.06 \%$ & $1.12 \%$ \\
\hline Czech Republic & $1.42 \%$ & $1.45 \%$ & $1.37 \%$ & $1.44 \%$ \\
\hline \multicolumn{5}{|c|}{$\begin{array}{l}\text { Share of outgoing Erasmus students as a percentage of the graduate population in the } \\
\text { two countries respectively }\end{array}$} \\
\hline Year & $2007 / 08$ & $2008 / 09$ & $2009 / 10$ & $2010 / 11$ \\
\hline Italy & $4.61 \%$ & $8.57 \%$ & $9.79 \%$ & $5.67 \%$ \\
\hline Czech Republic & $6.28 \%$ & $6.28 \%$ & $5.90 \%$ & $6.01 \%$ \\
\hline
\end{tabular}

(*Data is drawn from statistics report by European Commission)

Regarding the mobility between the east and west, we can see most of both countries' students prefer to go to the Western Europe, and most incoming Erasmus students in the two countries are also from the west (Table $2 \& 3$ ).

Table 2

Top 5 countries Italian and Czech students going to*

\begin{tabular}{|c|c|c|c|c|c|c|c|}
\hline \multicolumn{4}{|c|}{$2009-2010$} & \multicolumn{4}{|c|}{$2010-2011$} \\
\hline \multicolumn{2}{|c|}{ Italy } & \multicolumn{2}{|c|}{ Czech Republic } & \multicolumn{2}{|c|}{ Italy } & \multicolumn{2}{|c|}{ Czech Republic } \\
\hline Country & Number & Country & Number & Country & Number & Country & Number \\
\hline Spain & 7191 & Germany & 909 & Spain & 7547 & Germany & 947 \\
\hline France & 3275 & France & 701 & France & 3338 & France & 724 \\
\hline Germany & 2030 & Spain & 601 & Germany & 2199 & Spain & 685 \\
\hline UK & 1758 & UK & 532 & UK & 1849 & UK & 572 \\
\hline Portugal & 1022 & Austria & 352 & Portugal & 1011 & Portugal & 352 \\
\hline
\end{tabular}


Liu (2018). Education Reform Journal, 2018, 3(1), 24-31

Table 2 (continued)

\begin{tabular}{|c|c|c|c|c|c|c|c|}
\hline \multicolumn{4}{|c|}{$2011-2012$} & \multicolumn{4}{|c|}{ 2014-2015 } \\
\hline \multicolumn{2}{|c|}{ Italy } & \multicolumn{2}{|c|}{ Czech Republic } & \multicolumn{2}{|c|}{ Italy } & \multicolumn{2}{|c|}{ Czech Republic } \\
\hline Country & Number & Country & Number & Country & Number & Country & Number \\
\hline Spain & 7652 & Germany & 1046 & Spain & 9029 & Germany & 1277 \\
\hline France & 3300 & France & 803 & Germany & 3776 & France & 759 \\
\hline Germany & 2381 & Spain & 721 & France & 4129 & Spain & 751 \\
\hline UK & 2037 & UK & 552 & UK & 2704 & UK & 602 \\
\hline Portugal & 1150 & Finland & 381 & Portugal & 1636 & Austria & 408 \\
\hline
\end{tabular}

\begin{tabular}{lccc}
\hline \multicolumn{4}{c}{ 2015-2016 } \\
\hline \multicolumn{2}{c}{ Italy } & \multicolumn{1}{c}{ Czech Republic } \\
Country & Number & Country & Number \\
\hline Spain & 10030 & Germany & 1170 \\
\hline France & 4332 & Spain & 767 \\
\hline Germany & 4063 & France & 669 \\
\hline UK & 3114 & UK & 616
\end{tabular}

\begin{tabular}{lll}
\hline Portugal & $1822 \quad$ Portugal & 526
\end{tabular}

(*Data is drawn from statistics report by European Commission. Data of year 2013-2014 cannot be found)

Table 3

Top 5 countries of incoming Erasmus students in Italy and Czech Republic*

\begin{tabular}{|c|c|c|c|c|c|c|c|}
\hline \multicolumn{4}{|c|}{$2009-2010$} & \multicolumn{4}{|c|}{ 2010-2011 } \\
\hline \multicolumn{2}{|c|}{ Italy } & \multicolumn{2}{|c|}{ Czech Republic } & \multicolumn{2}{|c|}{ Italy } & \multicolumn{2}{|c|}{ Czech Republic } \\
\hline Country & Number & Country & Number & Country & Number & Country & Number \\
\hline Spain & 7063 & Spain & 611 & Spain & 8075 & Spain & 771 \\
\hline France & 1803 & France & 537 & France & 1834 & France & 630 \\
\hline Germany & 1663 & Poland & 516 & Germany & 1549 & Poland & 555 \\
\hline Poland & 1208 & Germany & 431 & Poland & 1212 & Turkey & 498 \\
\hline Portugal & 894 & Turkey & 384 & Turkey & 954 & Slovakia & 424 \\
\hline
\end{tabular}


Table 3 (continued)

\begin{tabular}{|c|c|c|c|c|c|c|c|}
\hline \multicolumn{4}{|c|}{$2011-2012$} & \multicolumn{4}{|c|}{ 2014-2015 } \\
\hline \multicolumn{2}{|c|}{ Italy } & \multicolumn{2}{|c|}{ Czech Republic } & \multicolumn{2}{|c|}{ Italy } & \multicolumn{2}{|c|}{ Czech Republic } \\
\hline Country & Number & Country & Number & Country & Number & Country & Number \\
\hline Spain & 8277 & Spain & 948 & Spain & 6994 & Spain & 1079 \\
\hline France & 1847 & France & 678 & France & 2276 & France & 1047 \\
\hline Germany & 1785 & Turkey & 575 & Germany & 2194 & Slovakia & 920 \\
\hline \begin{tabular}{|l|} 
Poland \\
\end{tabular} & 1326 & Poland & 516 & Poland & 1574 & Turkey & 718 \\
\hline \begin{tabular}{|l|} 
Turkey \\
\end{tabular} & 1095 & Slovakia & 499 & Turkey & 1232 & Poland & 707 \\
\hline \multicolumn{4}{|c|}{$2015-2016$} & & & & \\
\hline \multicolumn{2}{|c|}{ Italy } & \multicolumn{2}{|c|}{ Czech Republic } & & & & \\
\hline Country & Number & Country & Number & & & & \\
\hline Spain & 7470 & Spain & 1235 & & & & \\
\hline France & 2435 & Slovakia & 1017 & & & & \\
\hline Germany & 2320 & France & 985 & & & & \\
\hline Poland & 1668 & Turkey & 845 & & & & \\
\hline Turkey & 1320 & Germany & 780 & & & & \\
\hline
\end{tabular}

(*Data is drawn from statistics report by European Commission. Data of year 2013-2014 cannot be found)

Both countries' students believe three-cycle system and ECTS transfer system have made their mobility easier than before. However, according to the questionnaire survey and interview, both also believe that mobility like Erasmus has been intensifying inequality of higher education across Europe since the fund is so limited and normally only wealthy families can afford to send their children abroad. And both are concerned about the negative impact of international mobility on their study at home university.

\section{Conclusion}

Mobility programs like Erasmus were established as a catalyst to mobilize those who would not go without an additional stimulus. And Bologna Process aims to encourage mobility across Europe. According to the questionnaire survey on a sample of students, threecycle system and ECTS transfer system that Bologna Process proposed indeed have a positive effect on their mobility, though there was not a sudden growth in students' mobility of the two countries after the implementation of Bologna Process. However, there are also some limitations and problems to such mobility that Bologna Process has not solved yet. Based on the data statistics and questionnaire survey, students' mobility flows too much to the Western 
Europe and the inter-mobility between the west and the east is quite weak. Such onedirection flow limits the further development of education in the Eastern Europe and forms an unbalanced situation in the European continent. Moreover, mobility programs further widen the gap between major cities and the rest. And many students are not satisfied with the insufficient fund that comes with Erasmus and believe that such kind of mobility intensify the inequality of higher education. Another important institutional limitation is that mobility abroad will probably negatively affect study at home university after coming back, which will absolutely damp students' enthusiasm in applying for mobility programs.

\section{Acknowledgement}

I would like to express my gratitude to Professor Serafina Pastore, Professor Nicola Coniglio and professor Lidia Greco for their academic guidance and proof reading. The last five months of my study at University of Bari Aldo Moro as a Global-Doc mobility student from Charles University has been very fruitful. This semester of exchange study will be one of the most precious experiences in my life.

\section{References}

Amaral, Alberto, Neave, Guy, Musselin, Christine, Maassen, Peter (2009). European Integration and the Governance of Higher Education and Research. Springer Netherlands, vol 26.

Ballatore, Magali, K. Ferede, Martha (2013). The Erasmus Programme in France, Italy and the United Kingdom: student mobility as a signal of distinction and privilege. European Educational Research Journal Volume 12 Number 4.

Ballarino, Gabriele, Perotti, Loris (2012). The Bologna Process in Italy. European Journal of Education, Vol. 47, No. 3, The Bologna Process Revisited (September 2012), pp. 348-363.

Bhattacharya, Arundhati (2009). The Bologna Process and the Making of 'European' Higher Education Area: A European Answer to the Forces of Globalization? Aarhus University.

Corbett, Anne (2010). Higher Education as a Form of European Integration: How Novel is the Bologna Process? UiO: ARENA Centre for European Studies.

Damiani, Maria Sticchi (2005). The Bologna Process and the Reform of the Italian Higher Education System. Beiträge zur Hochschulforschung, Heft 3, 27. Jahrgang.

Doleželová, Jana (2015). International students in the Czech Republic are most satisfied at Masaryk University. https://www.online.muni.cz/en/news/6596-international-students-in-theczech-republic-are-most-satisfied-at-the-masaryk-university

Durazzi, Niccolo (2014). The Italian admission system to higher education: Quality, Equity and Mobility Issues. CRUI: Conferenza dei Rettori delle Universita' Italiane.

EAIE (2014). On the waves of innovation: higher education in the Czech Republic. https://www.eaie.org/blog/higher-education-in-cz.html 
European Commission. Erasmus + statistics. http://ec.europa.eu/programmes/erasmusplus/about/statistics_en

Floud, Roderick (2006). The Bologna Process:Transforming European Higher Education. Change: The Magazine of Higher Learning, Volume 38.

Gasperoni, Giancarlo (2011). Reform of the Italian University Educational System and Evolution of Selected Characteristics of Its Graduates (2000-2009). Department of Communication Disciplines-University of Bologna, AlmaLaurea Inter-University Consortium.

Huisman, J, Van Der Wende, M (2004). The EU and Bologna: Are supra- and international initiatives threatening domestic agendas? European Journal of Education. vol 39, issue3, September 2004, Pages 349-357.

Johnston, Rosie (2007). Czech University from the Perspective of a foreign student. http://www.radio.cz/en/section/curraffrs/czech-university-from-the-perspective-of-a-foreignstudent

Jörgens, Lena (2017). The Bologna Process and its influence on the participation in the Erasmus program. University of Twente.

MIUR (2011), L’Universita' in cifre 2009-2010. Rome

More International Students Choosing Czech Republic (2018). https://prague.tv/en/s72/Directory/c205-Education/n13268-More-International-StudentsChoosing-Czech-Republic

Papatsiba, Vassiliki (2006). Making higher education more European through student mobility? Revisiting EU initiatives in the context of the Bologna Process. Comparative Education, Volume 42.

Radičev, Slobodan, Di Stefano, Livia (2010 ). Bologna Process and Students Mobility-Italy \& Serbia \& EU. XVI Skup TRENDOVI RAZVOJA: "BOLONJA 2010: STANJE, DILEME I PERSPEKTIVE” Kopaonik, 01. - 04. 03.

Rozsnyai, Christina (2003). Quality Assurance Before and After 'Bologna' in the Central and Eastern Region of the European Higher Education Area with a Focus on Hungary, the Czech Republic and Poland. European Journal of Education, Vol. 38, No. 3 (Sep., 2003), pp. 271284.

S. Terry, Laurel (2010). The Bologna Process and Its Impact in Europe: It's So Much More than Degree Changes. Vanderbilt Journal of Transnational Law, vol 41:107.

Stastna, Vera (2001). Internationalisation of Higher Education in the Czech Republic-the impact of European Union Programmes. European Journal of Education, Vol. 36, No. 4. 
Statistics of Erasmus. http://ec.europa.eu/programmes/erasmus-plus/about/statistics_en https://data.europa.eu/euodp/it/data/publisher/46d36837-fde9-4eb9-a97ea30c497ce66b? tags $=$ student + mobility

Souto-Otero, M (2008). The Socio-economic Background of Erasmus Students: a trend towards wider inclusion? International Review of Education, 54, 135-154. http://dx.doi.org/10.1007/s11159-007-9081-9

Press and PR Office Charles University in Prague. Erasmus programme: if it's the Czech Republic, then Charles University (2014). https://www.cuni.cz/UKEN-316.html

U. Teichler \& V. Jahr (2001). Mobility during the Course of Study and After Graduation, European Journal of Education, 36(4), 443-458. http://dx.doi.org/10.1111/1467-3435.00081

U. Teichler (,2004). Temporary Study Abroad: the life of Erasmus students, European Journal of Education, 39(4), 395-408. http://dx.doi.org/10.1111/j.1465-3435.2004.00193.x

U. Teichler (2009b) Student Mobility and Staff Mobility in the European Higher Education Area Beyond 2010, in B.M. Kehm, J. Huisman \& B. Stensaker (Eds) The European Higher Education Area: perspectives on a moving target. Rotterdam: Sense.

U. Teichler (2012). International Student Mobility and the Bologna Process. Research in Comparative and International Education, Volume 7 Number 1. Germany.

Vossensteyn, H., Beerkens, M., Cremonini, L., et al (2010). Improving Participation in the Erasmus Programme. Report for Directorate-General for Internal Policies. Brussels: European Parliament Committee on Culture and Education.

Wächter, B (2008). Mobility and Internationalisation in the European Higher Education Area, in M. Kelo (Ed.) Beyond 2010: priorities and challenges for higher education in the next decade, pp. 13-42. Bonn: Lemmens. 